\title{
A Review of Fusarium Wilt of Oil Palm Caused by Fusarium oxysporum f. sp. elaeidis
}

\author{
Julie Flood
}

CABI Bioscience (UKC), Bakeham Lane, Egham, Surrey, UK.

Accepted for publication 12 January 2006.

\begin{abstract}
Flood, J. 2006. A review of Fusarium wilt of oil palm caused by Fusarium oxysporum f. sp. elaeidis. Phytopathology 96:660-662.

Vascular wilt is the most destructive disease of oil palm in Africa and causes severe losses in some areas. Symptoms include initial wilting followed by desiccation of the fronds, which finally break and hang around the trunk. Internally, characteristic browning of the vascular elements is seen both in adult palms and in seedlings. Two disease syndromes are commonly seen in the field in adult palms - "acute wilt" where the palm dies within a few weeks and "chronic wilt" where the

progressively stunted. The pathogen (Fusarium oxysporum f. sp. elaeidis) is a soilborne fungus and the perennial nature of the crop ensured that, in the past, disease management was difficult. Over a period of 30 to 40 years, screening for resistance at the nursery stage was introduced in many plantations and research stations, and successful breeding programs in West Africa, notably in Ivory Coast, have resulted in more resistant oil palm material becoming available. The disease has not yet been detected in South East Asia (largest producer of palm oil) and rigorous quarantine measures have been imposed to prevent introduction of the pathogen into these highly productive areas.
\end{abstract} palm may remain alive for many months and even years but becomes
Vascular wilt of oil palm (also called fusariose) is caused by the pathogen Fusarium oxysporum Schlechtend.:Fr. f. sp. elaeidis Toovey, a soilborne fungus that produces macroconidia, microconidia, and chlamydospores. Chlamydospores allow survival in plant debris and in soil. The primary host is Elaeis guineensis (African oil palm) but in artificial inoculations with isolates of the pathogen from West Africa, Elaeis oleifera (South American palm) also became infected (23). In addition, using artificial inoculation, isolates of $F$. oxysporum from roots of symptomless weed species (Amaranthus spinosus, Eupatorium odoratum, Mariscus alternifolius, and Imperata cylindrica) were pathogenic to seedling oil palm (18). This may indicate that these weeds act as a reservoir of inoculum for the pathogen in the field, although in the absence of further work, it is difficult to draw definite conclusions on the role of weeds as sources of inoculum.

The disease was first described in the Democratic Republic of Congo (26) and has subsequently been reported in Côte d'Ivoire, Nigeria, Ghana, Cameroon, and Congo. Localized outbreaks have also occurred in Brazil (25) and Ecuador (21). However, to date, the disease has never been reported from South East Asia, which is the region where most oil palm is grown.

Vascular wilt is the most destructive disease of oil palm in Africa and is particularly serious in replantings (1). For example, in some replantings, where palms are under 10 years old, a 50\% reduction in palm stand has been reported, although more generally, losses of 1 to $2 \%$ standing palms per annum occur (3). With regard to yield loss, Prendergast (20) generally considered this insignificant until a 20\% loss of palm stand had occurred. This "yield compensation" is thought to be due to increased vigor of

Corresponding author: J. Flood; E-mail address: j.flood@cabi.org

DOI: 10.1094/PHYTO-96-0660

(c) 2006 The American Phytopathological Society adjacent palms as they utilize the dead palms as extra sources of nutrients. However, Renard and de Franqueville (21) reported substantial yield reductions (from 6 to 16\%) in 6-year-old replanted palms when only a small percent ( 2.5 to $5.5 \%$ of plants) actually showed external symptoms. These authors attributed most of this yield reduction to 20 to $30 \%$ of palms that were actually infected but appeared healthy. Thus, subclinical levels of infection were having a large impact on yield even after only 6 years.

Disease symptoms. Two disease syndromes are seen in adult field palms. The first is "acute wilt" in which leaves dry out and die rapidly while retaining their original erect positions on the plant until broken off, usually several feet from the base, by wind action. The disease progresses rapidly and palms die within 2 or 3 months. The second is "chronic wilt" in which the palm remains alive for many months and even years but becomes progressively stunted. Here, the outer (older) fronds become desiccated and hang around the stem. These symptoms progress gradually with younger fronds becoming successively affected. At the same time, as the youngest fronds are produced in the crown, they remain erect but are often chlorotic and very much reduced in size (stunted); the net result is a flattening of the crown. The apex of the trunk may also be reduced in diameter. Palms can exist in this condition for several years (1). Various intermediate stages between the acute and chronic forms may occur. No difference in isolates from acute and chronic palms has been detected. At the nursery stage, infected palms also show progressive shortening of younger leaves giving the appearance of flattening the crown as well as desiccation and death of older leaves. Detailed studies on the physiology of the disease in the 1990s (12) indicated that stunting was due to a decrease in size of the petiole and leaf lamina, which was almost entirely caused by a reduction in cell division; changes in the level or activity of host gibberellins were suggested to be partly involved. Further studies (13) revealed that the younger (stunted) leaves were associated with prolonged mild water stress. The older (nonstunted) leaves that had formed before 
the pathogen had become established were severely and permanently water stressed. These authors suggested that production of smaller leaves (as seen in chronic wilt) was an adaptation to prolonged mild water stress and speculated that, where palms failed to produce smaller leaves, acute wilting resulted.

Internally, characteristic (diagnostic) browning of the vascular elements is seen both in adult palms and in seedlings (1). Under a microscope, blockage of xylem vessels with tyloses and gums can easily be observed, but even in highly diseased field palms, most roots show no signs of infection $(11,20)$.

The host-pathogen interaction. As with many vascular wilt pathogens, the fungus invades the roots and grows directly to the vascular elements. Both wounded and uninjured roots are penetrated (1). Colonization of the xylem continues by microconidia carried in the transpiration stream until the vessel end wall is reached. The fungus grows through the end wall and produces microconidia on the other side of the end wall in order to colonize the next xylem vessel. During the time that the pathogen has to grow through the end wall, the host has time to limit its spread through the production of gums, gels, and tyloses that impede transpiration (19).

In resistant material, production of tyloses, gels, etc. is very rapid and is accompanied by the accumulation of antifungal compounds. Both preformed and induced antifungals are produced in oil palm, although their identity was not established (14). Thus, occlusion of the vessels restricts further fungal colonization and allows the accumulation of antifungals to inhibitory levels. This occurs both in the invaded vessels and, critically, in the vessels above and adjacent to the invaded vessel. In susceptible material, tyloses and gels are also produced but their production is slower as is the rate of accumulation of antifungal compounds. This allows the pathogen to colonize further vessels, leading to more vascular occlusion and ultimately to the external symptoms $(1,19)$.

Epidemiology. The pathogen is soilborne and spread is thought to occur through root contact with dead, infected palm tissue (21). Palms killed by the pathogen become sources of nutrients for adjacent palms and these too become infected. Statistically, infected palms tend to occur in pairs or groups (1). Contamination of oil palm seeds by the pathogen has also been reported, both on the outside of seeds (10) and the kernel surface (6). Levels of contamination vary considerably between seed consignments and between individual seeds. $F$. oxysporum has been detected on the seed surface of $50 \%$ of commercial seed samples (10 seeds examined per sample) at levels up to 5,000 CFU per seed and, with the same seeds, on the kernel surface in $30 \%$ of samples at levels up to $100 \mathrm{CFU}$ per kernel. In limited trials, these isolates were shown to be pathogenic (6).

As oil palm seeds are the subject of global breeding programs, there is a risk of long-distance transmission on contaminated seeds. Thus, the possibility of contaminated seeds giving rise to infected plants has been investigated (7). Because commercial seeds vary so much in levels of contamination, artificially infested seeds were used in a glasshouse study in the UK. Approximately $3 \%$ of seedlings from artificially infested seeds developed wilt, which would suggest that seed transmission is possible (7).

Limited outbreaks of Fusarium wilt of oil palm were reported from Brazil in 1984 (25) and Ecuador in 1989 (21). These outbreaks were limited to one plantation each. Isolates from these outbreaks have been shown to have identical restriction fragment length polymorphism (RFLP) patterns to each other, and using nitrate nonutilizing (nit) mutants to detect vegetative (somatic) compatibility, it has been demonstrated that South American isolates were compatible with isolates from Ivory Coast $(9,16)$. A further study of a worldwide collection of $76 F$. oxysporum $\mathrm{f}$. sp. elaeidis isolates and $21 \mathrm{~F}$. oxysporum isolates from the soil of several palm groves using RFLPs (17) revealed that isolates from Brazil and Ecuador had the same restriction pattern as some pathogenic isolates from the Ivory Coast, again suggesting that they may have originated in Africa. This evidence would suggest that transmission via contaminated seeds has occurred and accounts for the outbreaks in South America, but it is also possible that the pathogen could have been exported on contaminated seed of a cover crop or on plant debris accompanying the seed $(\mathrm{H}$. de Franqueville, IRHO/CIRAD, Dabou, Côte d'Ivoire, personal communication, 1995).

Population genetics. Some preliminary work has been conducted on the population genetics of this pathogen. Flood et al. (9) reported that all pathogenic isolates from Zaire were vegetatively compatible with each other and were designated vegetative compatibility group (VCG) 0140, while another VCG (0141) occurred in Brazil (9). Later, Mouyna et al. (17) reported that South American isolates were compatible with isolates from Ivory Coast and allocated to VCG 0141. This high degree of genetic uniformity may reflect a situation where the host has selected certain VCGs that have become predominant although much more work on isolates from other African countries is needed.

In contrast, nonpathogenic isolates from oil palm plantation soils and roots of healthy palms (from Malaysia and from Zaire) showed a much higher degree of diversity using VCG analysis (9) and were allocated to VCGs 2020 to 2035. RFLP analysis supported this group of isolates as being genetically diverse. Such diversity among nonpathogenic strains has been similarly reported for many other F. oxysporum pathosystems.

Management of the disease. The soilborne nature of the pathogen and the perennial nature of the crop have made management of the disease difficult. Cultural practices such as the removal and burning of infected palms have been advocated but are impractical on a plantation level, and due to the interconnectedness of palm roots, many adjacent palms would also need to be removed. The use of Barchiaria (a grass) as a cover crop has been advocated (24) instead of the traditional cover crops such as Pueraria or Calapogonium caeruleum (nitrogen fixing legumes) which tend to increase incidence of the disease (1). The disease can also be controlled through better field management, e.g., disease incidence can be halved by planting new palms more than $2 \mathrm{~m}$ from old stumps (22). The application of potassium (24) is reported to reduce disease incidence, whereas spent bunch stalks applied to palm bases after factory processing increased disease levels (21).

However, despite some successes with field management, breeding for resistance remains the only practical long-term method of management for this disease. Breeding programs such as those in Ivory Coast have been successful, with the introduction of resistant varieties reducing losses in some areas from 20 to $30 \%$ to less than $3 \%$ (3). Yet breeding programs with a perennial crop are long term. At least 4 years and usually more than 7 years is needed to select material on the basis of natural infection in field trials; thus alternative, more rapid tests have been investigated to help speed up screening of germ plasm. These include the use of nursery tests, pre-nursery tests, and various experimental approaches (1).

Screening trials in the nursery where palms are deliberately inoculated have been introduced in several West African breeding programs and generally correlate well with field results. Nursery testing is optimized using standard fungal isolates of known concentration and with standard progenies of known performance in every trial for comparative purposes. Environmental conditions are also optimized, e.g., through use of shade to maintain best temperatures for the pathogen invasion. The results can be obtained in 6 months and these tests are able to screen out susceptible and very susceptible progenies before field testing, thus reducing time and space (1).

Nursery tests have many advantages but they still require several hundred seedlings of each of the tested progenies, and when using expensive tissue cultures plantlets, pre-nursery screen- 
ing trials have also been used. An example of a pre-nursery screen was initiated at the University of Bath in the 1990s to screen clonal material before being sent for testing in African nursery trials and, ultimately, in the field. Results could be obtained within 6 months using as few as 12 plantlets and allowed the identification of susceptible clones. The initiation of these trials (not conducted in oil palm growing areas) also had the advantage of allowing the testing of isolates from South America and various parts of West Africa. No significant cultivar-isolate interaction was observed (15), which indicated that resistant material selected in one area may remain resistant if grown in other areas, although significant variation in isolate aggressiveness has been reported $(2,5)$.

As a further development to aid screening for resistance and as a tool to study the host-pathogen interaction, a petiole infusion technique has been developed, which generally correlates well with known resistance. The advantage of this method was that, for the first time, it was possible to assess nondestructively the resistance of individual palms in only a few days (14). Thus, an individual palm could be selected and assessed using this method and could then be used as a parent for breeding. Previously, the resistance or susceptibility of an individual palm could only be assessed by destructive harvesting following a nursery trial (to reveal internal symptoms). As a result of this harvesting, these individual palms could take no further part in the breeding program although the resistance/susceptibility of the progeny (or cross from selected parents) would be known and identical crosses made for further use in breeding. This petiole technique has been tested in the field (1) and is also a useful method for investigating the production of antifungal compounds in oil palm (14).

Oil palm breeding programs can involve partners from several countries and because there is a threat of seed transmission, oil palm seeds are now subject to strict quarantine regulations, especially where seeds from the center of diversity (West Africa) are being sent to South East Asia. It is recommended that all oil palm seeds go through intermediate quarantine with inspection and chemical seed treatment. Vacuum infiltration of seeds with fungicide (8) is recommended. Working with the Malaysian Palm Oil Board (MPOB), CABI Bioscience continues to provide such intermediate quarantine and, together with rigorous post-entry quarantine in Malaysia, this has allowed establishment of an oil palm germ plasm collection for use in breeding programs (4).

Conclusions. Vascular wilt is the most destructive disease of oil palm in Africa, causing severe losses in some areas. Two disease syndromes are observed-acute or rapid wilt and chronic wilt where the palm remains alive for some time but becomes progressively stunted. Physiological experimentation suggests that stunting is an adaptation to prolonged mild water stress.

There have also been limited outbreaks of the disease in South America and molecular and genetic studies suggest these outbreaks could be due to seed transmission. Intermediate quarantine with seed treatment is recommended and together with post-entry quarantine has allowed safe importation of germ plasm from the center of origin for use in breeding programs in Malaysia. However, constant vigilance is needed to maintain disease-free status in South East Asia.

Management of the disease is difficult given the soilborne nature of the pathogen and the perennial nature of the crop, but successful breeding programs in West Africa, notably in Ivory Coast, have resulted in more resistant oil palm material becoming available. Dramatic reductions in losses from this disease have been reported from some areas following introduction of this resistant material.

\section{LITERATURE CITED}

1. Corley, H., and Tinker, B. 2003. The Oil Palm. Blackwell Scientific Press, Oxford.

2. de Franqueville, H. 1991. Former savannah or former forest: Effect of pathogen isolate on the performance of oil palm families with respect to Fusarium wilt. Oleagineux 46:179-186.

3. de Franqueville, H., and Renard, J. L. 1990. Improvement of palm vascular wilt tolerance. Results and development of the disease at the R. Michaux plantation. Oleagineux 45:399-405.

4. Flood, J. 2004. Diseases and treatments of seed and nursery materials. Pages 209-217 in: Proceedings of the International Conference on Pests \& Diseases of Importance to the Oil Palm Industry. Malaysian Palm Oil Board, Kuala, Lumpur.

5. Flood, J., Cooper, R. M., and Lees, P. E. 1989. An investigation of pathogenicity of four isolates of Fusarium oxysporum from South America, Africa and Malaysia to clonal oil palm. J. Phytopathol. 124:80-88.

6. Flood, J., Mepsted, R., and Cooper, R. M. 1990. Contamination of oil palm pollen and seeds by Fusarium spp. Mycol. Res. 94:708-709.

7. Flood, J., Mepsted, R., and Cooper, R. M. 1994. Population dynamics of Fusarium species on oil palm seeds following chemical and heat treatments. Plant Pathol. 43:177-182.

8. Flood, J., Mepsted, R., Turner, S., and Cooper, R. M. 1994. Eradication of Fusarium from oil palm by seed treatments. Pages 201-205 in: Seed Treatment: Progress and Prospects: Proceedings of a Symposium held at the University of Kent, Canterbury, UK. BCPC Monogr. No. 57.

9. Flood, J., Whitehead, D. S., and Cooper, R. M. 1992. Vegetative compatibility and DNA polymorphisms in Fusarium oxysporum f. sp. elaeidis and their relationship to isolate virulence and origin. Physiol. Mol. Plant Pathol. 41:201-215.

10. Locke, T., and Colhoun, J. 1973. Fusarium oxysporum f. sp. elaeidis as a seed-borne pathogen. Trans. Br. Mycol. Soc. 60:594-595.

11. Mepsted, R. 1992. Studies on Fusarium wilt of oil palm. Ph.D. thesis. University of Bath, UK.

12. Mepsted, R., Flood, J., and Cooper, R. M. 1995. Fusarium wilt of oil palm I. Possible causes of stunting. Physiol. Mol. Plant Pathol. 46:361-372.

13. Mepsted, R., Flood, J., and Cooper, R. M. 1995. Fusarium wilt of oil palm II. Stunting as a mechanism to reduce water stress. Physiol. Mol. Plant Pathol. 46:373-387.

14. Mepsted, R., Flood, J., Paul, T. C., Airede, C., and Cooper, R. M. 1995. A model system for rapid selection of resistance and for investigation of resistance mechanisms in Fusarium wilt of oil palm. Plant Pathol. 44:749-755.

15. Mepsted, R., Flood, J., Paul, T. C., and Cooper, R. M. 1994. Virulence and aggressiveness in Fusarium oxysporum f. sp. elaeidis: Implications for screening for disease resistance. Oleagineux 49:209-211.

16. Mouyna, I., Renard, J. L., and Brygoo, Y. 1994. Characterization and DNA polymorphism in Fusarium oxysporum f. sp. elaeidis isolated from oil palm. Pages 1-11 in: Final Report. Defence Reaction Mechanism in Oil Palm with Respect to Fusarium oxysporum f. sp. elaeidis. Cytological studies and biochemical analyses. Application to the strengthening of selection criteria. J. L. Renard, ed. CIRAD-CP, Paris.

17. Mouyna, I., Renard, J. L., and Brygoo, Y. 1996. DNA polymorphism among Fusarium oxysporum f. sp. elaeidis populations from oil palm, using a repeated and dispersed sequence "Palm". Curr. Genet. 30:174-180.

18. Oritsejafor, J. J. 1986. Weed hosts of Fusarium oxysporum f. sp. elaeidis. Oleagineux 41:1-7.

19. Paul, T. 1995. Fusarium wilt of oil palm. Studies on resistance and pathogenicity. Ph.D. thesis. University of Bath, UK.

20. Prendergast, A. G. 1957. Observations on the epidemiology of vascular wilt disease of the oil palm (Elaeis guineensis Jacq.). J. W. Afr. Inst. Oil Palm Res. 2:148-175.

21. Renard, J. L., and de Franqueville, H. 1989. Oil palm vascular wilt. Oleagineux 44:342-347.

22. Renard, J. L., and de Franqueville, H. 1991. Effectiveness of crop techniques in the integrated control of oil palm vascular wilt disease. Oleagineux 46:255-265.

23. Renard, J. L., Noiret, J. M., and Meunier, J. 1980. Sources and ranges of resistance to Fusarium wilt in the oil palms Elaeis guineensis and Elaeis melanococca. Oleagineux 35:387-393.

24. Renard, J. L., and Quillec, G. 1983. Fusarium disease and replanting. Elements to be considered when replanting oil palm in a Fusarium zone in West Africa. Oleagineux 38:421-427.

25. Van de Lande, H. L. 1984. Vascular wilt disease of oil palm (Elaeis guineensis Jacq.) in Para, Brazil. Oil Palm News 28:6-10.

26. Wardlaw, C. W. 1946. Fusarium oxysporum on the oil palm. Nature 158:712. 